www.jmscr.igmpublication.org

Impact Factor 5.84

Index Copernicus Value: 83.27

ISSN (e)-2347-176x ISSN (p) 2455-0450

crossref DOI: _https://dx.doi.org/10.18535/jmscr/v5i7.127

Journal Of Medical Science And Clinical Research

IGM Publication

An Official Publication of IGM Publication

\title{
Study of Fetomaternal Outcome in Patients of Moderate and Severe Anaemia in > 28 Week Pregnancy
}

\author{
Authors \\ Dr Ashram Khatana ${ }^{1}$, Dr Kanti Yadav ${ }^{2}$
}

${ }^{1}$ PG Resident $\left(3^{\text {rd }}\right)$, Department of Obstetrics \& Gynaecology, J.L.N Medical College, Ajmer, Rajasthan

${ }^{2}$ Sr. Professor \& Head, Dept. of Obstetrics \& Gynaecology, J.L.N Medical College, Ajmer, Rajasthan

\begin{abstract}
Background: Anaemia in pregnancy is one of the most common problems faced by obstetrician, especially in developing countries. These large differences in risk are related primarily to differences in available obstetric care for women living in areas with inadequate antenatal and delivery care facilities. The our aim of this study to fetomaternal outcome in patients of moderate and severe anaemia in pregnancy.

Material \& Methods: A prospective study was conducted in the department of Obstetrics and Gynaecology, J.L.N. hospital, Ajmer from Oct 2015 to Dec 2016. The study was undertaken to find out prevalence of anaemia in pregnancy, $\mathrm{Hb}$ status of pregnant women, magnitude of anaemia and fetomaternal outcome of anaemic patients. Out of a total of 1000 pregnant women admitted in labour room for delivery, 325 patients had moderate to severe anaemia and were included in this study.

Results: Out of 1000 cases admitted in labour room 325 cases had moderate to severe anaemia and they were studied to find out fetomaternal complications. Perinatal mortality was also very high in cases of severe anaemia $42 \%$. Moderate to severe anaemia was associated with complications in $53.84 \%$ cases. Fetal outcome in present study was in form of $49.23 \%$ premature (Gestation age $<37$ weeks) birth with $33.12 \%$ perinatal mortality.

Conclusion: It can be concluded from present study that severe anaemia is associated with high maternal and fetal morbidity and mortality. It is also associated with high incidence of complication like congestive cardiac failure, toxaemia of pregnancy, preterm labour and post partum haemorrhage.

Keywords: Anaemia, Antenatal, postnatal, maternal, fetal.
\end{abstract}

\section{Introduction}

Anaemia in pregnancy is one of the most common problems faced by obstetrician, especially in developing countries. It is the major cause of maternal mortality in India. Globally $50 \%$ of the anaemia is assumed to be attributable to iron deficiency. An adult man needs a daily amount of $1.1 \mathrm{mg}$ of iron, compared with twice as much by a woman when she is not pregnant. The total iron needed during pregnancy is about $1000 \mathrm{mg}$. The daily requirements for iron, as well as folate, are 6 times greater for a woman in the last trimester of pregnancy than for a non pregnant woman. ${ }^{1}$

Nearly 6, 00, 000 women die each year as a result of complication of pregnancy and childbirth; most of these deaths could be prevented with attainable resources and skill (WHO 1996). The worldwide maternal mortality (annual number of deaths of 
women due to pregnancy related causes per 100 , 000 live births) is estimated to be 239 per 100 , 000 live birth (WHO-2015). Most of these occur in developing countries, which have a risk of dying in pregnancy and childbirth that is $50-100$ times greater than that of women in the developed world. These large differences in risk are related primarily to differences in available obstetric care for women living in areas with inadequate antenatal and delivery care facilities. Harrison (1975) highlighted the importance of maternal anaemia as a contributory factor to maternal death. $^{2}$

In 1987, international agencies and leaders from 45 countries established the safe motherhood initiative. A key component of safe motherhood is the eradication of anaemia during pregnancy.

Anaemia is defined as reduction in the circulating red cell mass and corresponding decrease in $\mathrm{Hb}$ mass and oxygen carrying capacity of blood. In 1972 the WHO expert group recommended that pregnant women with haemoglobin level below $11 \mathrm{gm} / \mathrm{d} 1(\mathrm{PCV} 33 \%)$ should be considered anaemic. In practice in India a level of $10 \mathrm{gm} / \mathrm{d} 1$ may be more realistic. Anaemia is a clinical feature and not a disease. It is a major public health hazard where nearly 40 to $90 \%$ of pregnant women are considered anaemic. It contributes directly to $20 \%$ of maternal deaths and indirectly to a further $20 \%{ }^{3}$ The our aim of this study to fetomaternal outcome in patients of moderate and severe anaemia in pregnancy.

\section{Material \& Methods}

A prospective study was conducted in the department of Obstetrics and Gynaecology, J.L.N. hospital, Ajmer from Oct 2015 to Dec 2016. The study was undertaken to find out prevalence of anaemia in pregnancy, $\mathrm{Hb}$ status of pregnant women, magnitude of anaemia and fetomaternal outcome of anaemic patients.

Out of a total of 1000 pregnant women admitted in labour room for delivery, 325 patients had moderate to severe anaemia and were included in this study.
- Moderate anaemia had $\mathrm{Hb}-7-8.9 \mathrm{gm}$

- Severe anaemia had $\mathrm{Hb} \quad-<7 \mathrm{gm} \%$

Patients with moderate to severe anaemia were investigated for haematocrit values, PBF, stool examination, complete urine examination. Where required special investigations such as X-ray chest, ECG and USG were done. All cases were studied in full details regarding literacy, socioeconomic status, addiction, occupation, parity, interval between conception, history of abortions, MTP and outcome of previous pregnancy.

Present pregnancy details regarding number of antenatal visits, ill health, chronic infection or infestation any time during pregnancy were studied.

Mode of interference, any operative interference in required were studied.

Intrapartum, postpartum and puerperal complications were studied.

Total outcome was judged by detailed neonatal examination at birth, during hospital stay. Maternal mortality and morbidity was noted.

\section{Results}

Out of 1000 cases admitted in labour room 325 cases had moderate to severe anaemia and they were studied to find out fetomaternal complications. Rest of the patients had either mild anaemia (475 cases) or no anaemia (200 cases) (table 1). So overall prevalence of anaemia in pregnancy was $80 \%$ in present study.

In this study it was observed that maternal mortality was very high in cases of severe anaemia $16 \%$. Perinatal mortality was also very high in cases of severe anaemia $42 \%$ (table 2). The observations show high incidence of fetal and maternal mortality associated with poor or no antenatal care (table 3 ).

Moderate to severe anaemia was associated with complications in $53.84 \%$ cases. PIH was observed in $17.14 \%$ of cases, eclampsia in $5.71 \%$ of cases. APH in $14.28 \%$ cases, $11.42 \%$ cases had congestive cardiac failure. Maternal mortality was $35 \%$ in congestive cardiac failure. Perinatal 
mortality was maximum in congestive cardiac failure group (table 4).

Incidence of maternal morbidity was $43.07 \%, 30$ cases had secondary PPH. 20 cases had puerperal sepsis, 50 cases had delayed involution and 40 cases had wound sepsis (table 5).
Fetal outcome in present study was in form of 49.23\% premature (Gestation age $<37$ weeks) birth with $33.12 \%$ perinatal mortality. There was $21.53 \%$ of mature babies with normal birth weight with $7.14 \%$ perinatal mortality and $29.23 \%$ of mature with low birth weight babies (weight $<2.5$ $\mathrm{kg}$ ) with $14.73 \%$ perinatal mortality (table 6 ).

Table 1: Prevalence of anaemia in pregnancy

\begin{tabular}{|l|c|c|}
\hline Degree of anaemia & Number of cases & Percentage $(\%)$ \\
\hline No anemia & 200 & 20 \\
\hline Mild & 475 & 47.5 \\
\hline Moderate & 225 & 22.5 \\
\hline Severe & 100 & 10 \\
\hline Total & 1000 & 100 \\
\hline
\end{tabular}

Table 2: Perinatal and maternal outcome in relation to degree of anaemia

\begin{tabular}{|l|c|c|c|c|c|c|}
\hline \multirow{2}{*}{$\begin{array}{l}\text { Degree of } \\
\text { anaemia }\end{array}$} & \multirow{2}{*}{$\begin{array}{c}\text { No. Of } \\
\text { Cases }\end{array}$} & \multirow{2}{*}{$\%$} & \multicolumn{2}{|c|}{$\begin{array}{c}\text { Maternal } \\
\text { Mortality }\end{array}$} & \multicolumn{2}{c|}{$\begin{array}{c}\text { Perinatal } \\
\text { Mortality }\end{array}$} \\
\cline { 4 - 7 } & & & No. Of cases & $\%$ & No. Of cases & $\%$ \\
\hline Moderate & 225 & 22.5 & 2 & 0.89 & 30 & 13.3 \\
\hline severe & 100 & 10 & 16 & 16 & 42 & 42 \\
\hline
\end{tabular}

Table 3: Anaemia in relation to antenatal care

\begin{tabular}{|l|c|c|c|c|c|c|}
\hline \multirow{2}{*}{ Antenatal visit } & \multirow{2}{*}{$\begin{array}{c}\text { No. of } \\
\text { cases }\end{array}$} & \multirow{2}{*}{$\%$} & \multicolumn{2}{|c|}{$\begin{array}{c}\text { Maternal } \\
\text { Mortality }\end{array}$} & \multicolumn{2}{|c|}{$\begin{array}{c}\text { Perinatal } \\
\text { mortality }\end{array}$} \\
\cline { 4 - 8 } & & & $\begin{array}{c}\text { No. of } \\
\text { cases }\end{array}$ & $\%$ & $\begin{array}{c}\text { No. of } \\
\text { cases }\end{array}$ & $\%$ \\
\hline $\begin{array}{l}\text { Moderate anaemia } \\
\text { antenatal visit }\end{array}$ & 50 & 22.22 & 0 & 0 & 3 & 6 \\
\hline No previous antenatal visit & 175 & 77.77 & 2 & 1.14 & 30 & 17.14 \\
\hline $\begin{array}{l}\text { Severe anaemia previous } \\
\text { antenatal visit }\end{array}$ & 10 & 10 & 1 & 10 & 2 & 20 \\
\hline No previous antenatal visit & 90 & 90 & 15 & 37 & 37 & 41.11 \\
\hline
\end{tabular}

Table 4: Associated obstetrical and medical complications in patients of anaemia

\begin{tabular}{|c|c|c|c|c|c|c|}
\hline & \multirow{2}{*}{$\begin{array}{l}\text { No. of } \\
\text { cases }\end{array}$} & \multirow{2}{*}{$\%$} & \multicolumn{2}{|c|}{$\begin{array}{l}\text { Maternal } \\
\text { Mortality }\end{array}$} & \multicolumn{2}{|c|}{$\begin{array}{l}\text { Perinatal } \\
\text { mortality }\end{array}$} \\
\hline & & & $\begin{array}{l}\text { No. of } \\
\text { Cases }\end{array}$ & $\%$ & $\begin{array}{l}\text { No. of } \\
\text { cases }\end{array}$ & $\%$ \\
\hline Congestive cardiac failure & 20 & 11.42 & 7 & 35.00 & 14 & 70.00 \\
\hline Pregnancy induced hypertension & 30 & 17.14 & 2 & 6.66 & 4 & 13.33 \\
\hline Eclampsia & 10 & 5.71 & 2 & 20.00 & 6 & 60.00 \\
\hline Accidental haemorrhage & 25 & 14.28 & 5 & 20.00 & 15 & 60.00 \\
\hline Placenta previa & 15 & 8.57 & 2 & 13.33 & 8 & 53.33 \\
\hline Preterm labour & 75 & 42.85 & 0 & 0 & 25 & 33.33 \\
\hline
\end{tabular}

Table 5: Maternal morbidity in anaemia

\begin{tabular}{|l|c|c|}
\hline & No. of cases & Percentage \\
\hline Secondary PPH & 30 & 9.23 \\
\hline Puerperal sepsis & 20 & 6.15 \\
\hline Delayed in volution & 50 & 15.38 \\
\hline Wound sepsis & 40 & 12.30 \\
\hline
\end{tabular}


Table 6: Fetal outcome in anaemia patients

\begin{tabular}{|l|c|c|c|c|}
\hline & \multirow{2}{*}{ No. Of cases } & \multirow{2}{*}{$\%$} & \multicolumn{2}{|c|}{$\begin{array}{c}\text { Perinatal } \\
\text { mortality }\end{array}$} \\
\cline { 4 - 5 } & & & No. Of cases & $\%$ \\
\hline Mature with normal birth weight & 70 & 21.53 & 5 & 7.14 \\
\hline Mature with low birth weight & 95 & 29.23 & 14 & 14.73 \\
\hline Premature & 160 & 49.23 & 53 & 33.12 \\
\hline
\end{tabular}

\section{Discussion}

The prevalence of anaemia varied in the patients. In the present study 475 patients were found to have mild anaemia ( $\mathrm{Hb} 9-11 \%$ ) which accounted for $47.5 \%$ of the total cases observed. $22.5 \%$ had moderate anaemia ( $\mathrm{Hb} 7-8.9 \%)$. Severe anaemia $(\mathrm{Hb}<7 \mathrm{gm} \%)$ was observed in $10 \%$ of cases. So overall prevalence of anaemia in pregnancy was $80 \%$ in present study. Luwung N.C. et al $^{4}$ reported prevalence of anaemia to be $75 \%$ patients in which $\mathrm{Hb}$ was less than $10 \mathrm{gm} \%$. Modok ${ }^{5}$ observed prevalence of anaemia was $81.5 \%$. $12 \%$ cases was had severe anaemia. Gupta et $\mathrm{al}^{6}$ in Jaipur observed total prevalence of anaemia to be $90.6 \%$.

In this study it was observed that maternal mortality was very high in cases of severe anaemia $16 \%$. Perinatal mortality was also very high in cases of severe anaemia $42 \%$. Uday Donade et $\mathrm{al}^{7}$ found that the incidence of perinatal death was $36 \%$ in severe anaemia, $12.2 \%$ in mild anaemia while $5.3 \%$ in patients with $\mathrm{Hb} 10 \mathrm{gm} \%$ which is comparable with our study. Diallo M.S. ${ }^{8}$ reported $65 \%$ maternal mortality was due to anaemia.

The WHO study of maternal mortality in India (Bhatt. 1996) ${ }^{9}$ states that anaemia was the cause of maternal death in $64.4 \%$ of cases.

Out of 100 cases of severe anaemia, $90 \%$ had no previous antenatal visit and $10 \%$ had one or two antenatal visit. Out of 90 cases with no previous antenatal visit maternal mortality was $16.66 \%$ as compared to $10 \%$ in cases who had antenatal visit. Perinatal mortality was $20 \%$ in cases who had previous antenatal visit and $41.11 \%$ in cases who had no previous antenatal visit. The observations show high incidence of fetal and maternal mortality associated with poor or no antenatal care. Rosario et al reported that $90 \%$ unbooked cases had severe anaemia. Same was observed in the present study $90 \%$ cases of severe anaemia had no antenatal visit while he reported $75.5 \%$ cases of moderate anaemia and $66.2 \%$ cases of mild anaemia had antenatal visit.

Dasgupta $\mathrm{S}$. et $\mathrm{al}^{10}$ reported that severe anaemia accounted $13 \%$ of perinatal mortality. About $85.9 \%$ of the mothers did not receive adequate antenatal care services.

Congestive cardiac failure usually occurs in $3^{\text {rd }}$ trimester of pregnancy due to increased workload on heart. Very high incidence of CCF of $78 \%$ was observed by Satyanarayan et al (1984) ${ }^{11}$, Rosario et al $(1971)^{12}$ and Rathee et al $(1987)^{13}$ reported incidence of $18.75 \%$ and $15.19 \%$ respectively same as present study. PIH was observed in $25 \%$ cases of Rosario et al (1971) ${ }^{12}$ series Rathee et al $(1987)^{13}$ encountered PIH and eclampsia in $5.17 \%$ and $2.3 \%$ respectively.

Singhal U, Saxena K. ${ }^{14}$ Studies the effect of anaemia on respiratory and metabolic parameters during third trimester of pregnancy. They found $\mathrm{O}_{2}$ uptake, $\mathrm{CO}_{2}$ output, respiratory exchange ratio, resting metabolic rate were significant increased whereas PEFR was significant decreased in anaemic than in normal subjects during third trimester of pregnancy.

Incidence of maternal morbidity was $43.07 \%, 30$ cases had secondary PPH. 20 cases had puerperal sepsis, 50 cases had delayed involution and 40 cases had wound sepsis. Chatterjee et $\mathrm{al}^{15}$ reported $53.5 \%$ maternal morbidity in anaemia. Pandy et $\mathrm{al}^{16}$ observed puerperal sepsis, in 22.3, wound sepsis in $11.8 \%$ delayed involution in $31.5 \%$ and secondary PPH in $33 \%$ cases.

Anaemia is not only dangerous for mother but also threatens life and well being of fetus. Prematurity, still birth. IUGR and congenital malformation are associated with anaemia. 
Chatterjee et $\mathrm{al}^{15}$ and Rangnakar et $\mathrm{al}^{17}$ reported highest incidence of prematurity being $35.5 \%$ and $82.4 \%$ in severe anaemia. Least incidence of $24 \%$ was reported by Satyanarayan et al while Pandya et $\mathrm{al}^{16}$ and Achari et $\mathrm{al}^{18}$ recorded incidence of prematurity was $55.2 \%$ and $4 \%$ same as present study.

Rangankar et $\mathrm{al}^{17}$ and Pandya et $\mathrm{al}^{16}$ reported high incidence of LBW babies being 82.4\%, 78.48\%, $79.5 \%$ respectively. While Rathee et $\mathrm{al}^{13}$ and Rosario et $\mathrm{al}^{12}$ have reported incidence of $61.75 \%$ and $65.5 \%$.

Rathee et $\mathrm{al}^{13}$, Roy et $\mathrm{al}^{12}$ had reported high incidence of still birth being $33.7 \%$ and $32.3 \%$ respectively. Achari et $\mathrm{al}^{18}$ and Rangnekar A.G. et $\mathrm{al}^{17}$ reported incidence of SB being $16.07 \%$ and $10.8 \%$ which were comparable with present study. Single PN, Tyagi M, Kumar A, Dash D and Shankar $\mathrm{R}^{19}$ studied effect of maternal iron deficiency anaemia and fetal growth. He found that the birth weight, head circumference, chest circumference, mid arm circumference and crown heel length were significant low in infants born to women with moderate ( $\mathrm{Hb} 6.1$ to $8.5 \mathrm{gm} / \mathrm{dl}$ ) and severe anaemia $(\mathrm{Hb} \leq 6.0 \mathrm{gm} / \mathrm{dl})$. All indices of fetal growth showed linear relationship with maternal haemoglobin.

Das S. Gupta et $\mathrm{al}^{10}$ found severe anaemia was responsible for $13 \%$ of perinatal mortality cases.

\section{Conclusion}

It can be concluded from present study that severe anaemia is associated with high maternal and fetal morbidity and mortality. It is also associated with high incidence of complication like congestive cardiac failure, toxaemia of pregnancy, preterm labour and post partum haemorrhage.

It seems difficult to achieve this goal if concrete measures are not taken, not only in urban area but rural areas as well. The maternal and fetal outcome can only be improved if following certain measures are taken:

1) Removal of social inequities facing women in essential and attitude towards girl should be change.
2) Through out childhood and adolescence her nutrition should not be neglected.

3) Female literacy and education including vocational training should be improve which will improve employment opportunities to delayed marriage and fewer children.

4) Ensuring accent to family planning should be emphasized through health education material.

5) Community based maternity care should be made available and preexisting be improved at rural primary health centre.

6) All women should get adequate prenatal care at least four visits should be there one before 20 weeks, $2^{\text {nd }}$ by 28 weeks, $3^{\text {rd }}$ between $32-34$ weeks and $4^{\text {th }}$ at full term.

7) Iron and folic acid should be supplemented in all cases.

8) Hospital delivery should be advised in booked cases which will be safe for mother and fetus.

9) All high risk cases should be identified and should be referred to hospital in time.

Present study of anaemia has shown that there is higher incidence of maternal and fetal mortality associated with severe anaemia. This study that if adequate measures are taken to improve the maternal nutrition status from early weeks of pregnancy and supplementation of essential haemopoietic factor can atleast minimize the severity of anaemia if cannot prevent it completely. Thus, reducing the incidence of maternal and fetal mortality remarkably to achieve goal of safe motherhood.

\section{References}

1. J. G. Chopra, E. Noe, J. Matthew, C. Dhein, J. Rose, J. M. Cooperman and A. L. Luhby. Anaemia in pregnancy. Am J. Pub. Health, 1967;57: 857.

2. Cook J.D.: Nutritional deficiency and anaemia in Latin America. 1971;38(5): 591-603. 
3. World Health Organization: Control of Nutritional Anaemia with special reference of Iron Deficiency, Teach Resp. 1975; Series No. 580: 19.

4. Luwang NC, Gupta VM, Khanna $S$. Anemia in pregnancy in a rural community of Varanasi. Indian Journal of Preventive Social Medicine. 1980;11:83-8.

5. Modok G.C. Sikdar K: J. of Obstet. and Gynae. Of India, 605-607; 1980.

6. Gupta et al. Low anemia prevalence among adolescents of an urban hilly community. Ind. J. of PSM. 27: 28; 1983.

7. Donde Uday, Maitra Anurupa Joshi J.: J. of Obstet and Gynae. Of India. 41: 146$152 ; 1991$.

8. Diollo MS, Diollo FB, Camera AY: Franch J. of Obstet. and Gynae, 90(3): 138-141; 1995.

9. Bhatt Rohit V: J. of Obstet. and Gynae, of India, 46: 185-190; 1996.

10. Dasgupta S, Saha I, Lahiri A, Mandak Ak. India Medical Association 1997 Mar; 95(3): 78-9.

11. Satyanarayan Alli: J. of Obstet. and Gynae. of India, 35: 335-338; 1984.

12. Rosario Y. Pinto: J. of Obstet. and Gynae. of India, 21: 1-6; 1971.

13. Rathee S, Khosa A.: J. of Obstet. and Gynae. of India, 37: 478-480; 1987.

14. Singhal V, Saxena K, (1987) Indian J. Physiology and Pharmacology.

15. Chatterjee: J. of Obstet. and Gynae. of India, 20: 329; 1970.

16. Pandya P, Hazra M.N.: J. of Obstet. and Gynae. of India, 43: 5-10: 1993.

17. Rangnekar, Darbari: J. of Obstet. and Gynae. of India, 43: 172-176; 1993.

18. Achari K. Rani U.: J. of Obstet. and Gynae. Of India, 21 : 305 - 309; 1971.

19. Single PN, Tyagi M, Kumar A, Dash D and Shankra R. Fetal growth in maternal anaemia. J. Trop. Pediatr. 1997 Apr. 43(2); 89-92. 